\title{
Response of peat biogeochemistry and soil organic matter quality to rewetting in bogs and spruce swamp forests
}

\section{Urbanova, Zuzana}

2018-02-12

Urbanova , Z , Straková , P \& Kastovska , E 2018 , ' Response of peat biogeochemistry and soil organic matter quality to rewetting in bogs and spruce swamp forests ' , European Journal of Soil Biology , vol. 85 , pp. 12-22 . https://doi.org/10.1016/j.ejsobi.2017.12.004

http://hdl.handle.net/10138/308754

https://doi.org/10.1016/j.ejsobi.2017.12.004

cc_by_nc_nd

acceptedVersion

Downloaded from Helda, University of Helsinki institutional repository.

This is an electronic reprint of the original article.

This reprint may differ from the original in pagination and typographic detail.

Please cite the original version. 


\title{
Response of peat biogeochemistry and soil organic matter quality to rewetting in bogs and spruce swamp forests
}

Zuzana Urbanováa, ${ }^{a, *}$, Petra Straková, ${ }^{\mathrm{b}, \mathrm{c}}$, Eva Kaštovskáa

${ }^{a}$ Department of Ecosystem Biology, University of South Bohemia in České Budějovice, Branišovská 31a, 37005 České Budějovice, Czech Republic

${ }^{\mathrm{b}}$ Department of Forest Sciences, University of Helsinki, P. O. Box 27, FI-00014 University of Helsinki, Finland

${ }^{\mathrm{c}}$ Natural Resources Institute Finland (LUKE), Latokartanonkaari 9, FI-00790 Helsinki, Finland

*Corresponding author. E-mail address: urbanz00@prf.jcu.cz (Z. Urbanová)

\begin{abstract}
Various peatland restoration strategies developed during the last two decades have aimed to stop degradation and bring back the original hydrology, biodiversity and other peatland functions. This study evaluated progress 6-15 years after rewetting in vegetation development, physicochemical properties of peat, soil organic matter (SOM) quality and microbial activity in previously long-term drained bogs and spruce swamp forests (SSF) in comparison with pristine and long-term drained sites in the Bohemian Forest, Czech Republic.

Long-term drainage led to overall ecosystem degradation, indicated by a change in vegetation composition, reduced decomposability of peat, with high content of recalcitrant compounds and decreased $\mathrm{pH}$, and reduced soil microbial biomass and activity. The degradation was more pronounced in SSF, while bogs seemed to be relatively resistant to environmental changes caused by drainage. Post-rewetting progress has occurred with regard to vegetation
\end{abstract}


composition, peat $\mathrm{pH}$, microbial biomass and potential anaerobic $\mathrm{CO}_{2}$ and $\mathrm{CH}_{4}$ production, all of which tending towards characteristics of the pristine sites. However, overall SOM quality has not yet responded significantly, indicating that some peat properties and functions, such as $\mathrm{C}$ accumulation, need much longer periods of time to return to the original level.

\section{Introduction}

Peatlands accumulate organic matter under the prevailing waterlogged conditions, which constrain litter decomposition [1]. The position of the water table controls the balance between peat accumulation and decomposition. Therefore, peatland functioning is very sensitive to changes in hydrology that may be caused by climate or land use changes [1]. There is a strong argument for the protection and restoration of peatlands for the sake of the hydrological, biological and carbon (C) sequestration ecosystem services they offer $[2,3]$. In Central Europe, peatlands - as a relict boreal ecosystem - significantly contribute to biodiversity and play an important role in the hydrology of the landscape. However, most peatlands in this region were destroyed or have been disturbed by human activities $[4,5]$. The Bohemian Forest, including the Šumava National Park, is an exceptional area within Central Europe due to the abundance of peatlands; however, about $70 \%$ of them have been influenced by drainage. Large-scale restoration efforts were initiated more than a decade ago, with the aim of revitalising the bogs and spruce swamp forests (SSF) characteristic for this region.

Artificial drainage and peat mining disturb the natural processes of peat formation and accelerate soil organic matter (SOM) mineralisation, resulting in a net release of $\mathrm{C}[6]$. Drainage generally results in changes in vegetation composition accompanied by changed litter quality, which are followed by changes in peat physicochemical properties and nutrient availability $[5,7,8]$. Long-term exposure of the surface peat layers to aerobic decomposition in drained or cutaway peatlands results in decreased quality and decomposability of SOM. 
Labile SOM fractions are depleted and recalcitrant fractions predominate [9]. Low availability of substrate and unfavourable $\mathrm{C}: \mathrm{N}: \mathrm{P}$ stoichiometry of peat and incoming litter is reflected in decreased microbial biomass and activity [7, 10-12]. The extent of changes in ecosystem functioning (degradation) depends on the intensity of the disturbance. It also varies between different peatland types, with more pronounced draining effects in nutrient-richer minerotrophic fens than nutrient-poor and acidic ombrotrophic bogs [10, 13, 14]. Based on existing data from drained and restored peatlands, a more dynamic response to hydrological restoration can be expected in fens than in bogs, especially dieback of trees, changes in light conditions and relatively fast proliferation of the plant species characteristic of undrained sites [15-17].

A number of peatland restoration activities have been developed during the last two decades with the aim to stop degradation and bring back the original ecosystem functions such as peat formation, water retention and biodiversity $[2,18]$. Typical peatland vegetation can be quickly restored and is therefore the most visually obvious indicator of restoration progress, while recovery of other (belowground) ecosystem attributes may take longer [19, 20]. Microorganisms are the main drivers of SOM transformations and therefore their activity and abundance may reflect SOM quality and physicochemical properties [8, 10, 21]. Studies with cutaway peatlands determined that poor substrate quality was the main reason for low microbial biomass and low $\mathrm{CO}_{2}$ and $\mathrm{CH}_{4}$ production during the first years after rewetting [2224]. It is thus assumed that the spreading of peatland vegetation and accumulation of new litter following this intervention will lead to an improvement of SOM quality in the surface layer. This can be assessed by Fourier Transform Infrared (FTIR) spectra analysis of peat, which has been found a useful tool for evaluation of SOM composition and monitoring of restoration efforts [25]. Vegetation succession after rewetting can result in differences in $\mathrm{SOM}$ in terms of $\mathrm{C}$ availability, which can be reflected in increases of microbial biomass and 
activity [26]. For example, methanogenic archaea and $\mathrm{CH}_{4}$ dynamics are known to react sensitively to environmental changes $[10,27]$. Therefore, the regeneration of $\mathrm{CH}_{4}$ production after peatland rewetting might be considered not only as an indicator of stable anaerobic conditions but also of the re-establishment of original microbial processes and substrate availability [23]. Nurulita et al. [28] suggest that soil pH, enzyme activities and soil microbial diversity may be useful indicators in terms of monitoring restoration progress.

This study aimed to evaluate the succession of vegetation after the rewetting on previously long-term drained bogs and SSF and to investigate whether the vegetation shift is reflected belowground in peat physicochemical properties and shifts in microbial activities, including enzyme activity. Specifically, we (i) compared the responses of SSF and bogs to long-term drainage and rewetting with a focus on vegetation and peat biogeochemical properties, SOM quality and production of $\mathrm{CO}_{2}$ and $\mathrm{CH}_{4}$ and (ii) assessed the restoration progress in a SSF four years after a previous study by Mastný et al. [29], who evaluated SOM quality and microbial activity 3-7 years after rewetting of the same SSF study sites. (iii) Based on our results, we put forward ecologically meaningful indicators in order to improve future monitoring of restoration schemes.

We hypothesised that peat at long-term drained sites has a higher C:N:P stoichiometric ratio and a high proportion of recalcitrant SOM, resulting in low soil microbial activity. Rewetting connected with recolonisation by characteristic peatland vegetation will reverse this trend and peat properties will start to change back towards the original state. We expected that microbial activities driven by the input of recent plant assimilates would respond more rapidly than overall peat quality and enzyme activity linked to peat decomposition. Lastly, we expected that bogs would be more resistant and SSF more sensitive to shifts in hydrological conditions. 


\section{Material and Methods}

\subsection{Study sites}

We selected 12 sites in the Bohemian Forest, south-western Czech Republic (4859' N, $13^{\circ} 28^{\prime} \mathrm{E}$ ), representing two main types of peatlands: bogs (BOG) and spruce swamp forests (SSF). The study sites ranged in altitude from 1100 to $1260 \mathrm{~m}$ a.s.l.; mean annual precipitation was between 1000 and $1200 \mathrm{~mm}$ and mean annual temperature between 3.2 and $4^{\circ} \mathrm{C}$ (1961 to 1990 , statistics by the Czech Hydro-Meteorological Institute).

For each peatland type, six study sites were selected, two each of three different management types: i) pristine (unmanaged) peatlands (BOGp $n=2, \operatorname{SSFp} n=2$ ); ii) long-term drained peatlands (BOGd $n=2, \operatorname{SSFd} n=2)$; iii) rewetted (restored) peatlands after long-term drainage (BOGr $n=2$, SSFr $n=2$ ). The rewetting of the two BOGr sites was done 6 and 15 years and that of the two SSFr sites 6 and 9 years before this study, respectively. All the disturbed sites were drained in the 1960s to increase forest productivity; however, no tree planting or other type of management was carried out after drainage and the sites were left abandoned. Rewetting was achieved by blocking ditches, using timber dams and partial filling of ditches with organic material.

BOGp were dominated by common plant species characteristic for different microhabitats (hummocks, hollows and lawns) such as Andromeda polifolia, Vaccinium uliginosum, Eriophorum vaginatum, Carex limosa and Trichophorum caespitosum. Sphagnum rubellum, S. capillifolium and S. magellanicum dominated the moss layer. BOGd and BOGr mostly lacked the microtopographical variation of BOGp, especially the hollows, and were dominated by $V$. uliginosum, while young trees of Picea abies or Pinus x pseudopumilio proliferated on the driest places. The dwarf shrubs and trees partly died off along the dammed ditches in the BOGr sites, with original species such as E. vaginatum and Sphagnum mosses spreading. 
SSFp were also characterised by wetter and drier microhabitats occupied by heterogeneous vegetation, such as E. vaginatum together with other sedges and grasses or Vaccinium dwarf shrubs. The moss layer was dominated by S. fallax, S. flexuosum and $S$. girgensohnii. The tree canopy consisted of $P$. abies with a height of about 8-15 m, covering 0 70\%. SSFd were characterised by the wholly dominant $V$. myrtillus, a dense tree canopy $(P$. abies; $100 \%$ cover) with a height of about $20 \mathrm{~m}$ and a fragmented moss layer with greater cover of forest mosses (Pleurozium schreberi, Dicranum spp., Polytrichum commune, Hylocomnium splendens). On SSFr, E. vaginatum and Sphagnum mosses were spreading.

\subsection{Peat sampling and basic analyses}

The sampling procedure used a systematic design of six sampling plots within a $20 \times 20$ $\mathrm{m}^{2}$ area at each site. The sampling plots were placed in two parallel, $20 \mathrm{~m}$ long transects perpendicular to the ditch. On each transect, peat was sampled at a distance of 1,10 and $20 \mathrm{~m}$ from the drainage ditch. The vegetation was characterised near each sampling plot as \% cover for each plant species in a $1 \mathrm{~m}^{2}$ area. The hollows and tops of hummocks in bogs were not sampled. The water table was measured manually every other week during the growing season in perforated PVC tubes, whose spacing reflected the soil sampling design on each site.

Peat was sampled using a box corer $\left(6.5 \times 5.5 \mathrm{~cm}^{2}\right.$ inner dimension) to a depth of $30 \mathrm{~cm}$ and the cores were divided into upper $(0-10 \mathrm{~cm})$ and lower $(10-30 \mathrm{~cm})$ layers. The peat samples were homogenised by hand and woody material and roots were removed.

A portion of each sample was dried at $60^{\circ} \mathrm{C}$ to constant weight, milled and analysed for total $\mathrm{C}\left(\mathrm{C}_{\mathrm{TOT}}\right)$ and $\mathrm{N}\left(\mathrm{N}_{\mathrm{TOT}}\right)$ content with a Micro-cube elemental analyser (Elementar, Germany). Total $\mathrm{P}\left(\mathrm{P}_{\mathrm{TOT}}\right)$ was measured colorimetrically as orthophosphate on a flow injection analyser (FIA, Lachat QC8500, Lachat Instruments, USA) after perchloric acid 
digestion. Soil $\mathrm{pH}$ was measured after shaking $10 \mathrm{~g}$ of fresh sample with $25 \mathrm{~mL}$ of distilled water and letting it stand for 2 hours. Bulk density was determined by weighing the individual intact samples after drying at $70^{\circ} \mathrm{C}$.

\subsection{Microbial biomass and $\mathrm{CO}_{2}$ and $\mathrm{CH}_{4}$ production}

Soil microbial biomass $\mathrm{C}\left(\mathrm{C}_{\mathrm{mic}}\right)$ and $\mathrm{N}\left(\mathrm{N}_{\mathrm{mic}}\right)$ were measured after chloroform fumigationextraction of fresh peat samples [30]; concentrations of dissolved organic C and dissolved $\mathrm{N}$ in the soil solution were analysed with a LiquiTOC II (Elementar, Germany). $\mathrm{C}_{\text {mic }}$ and $\mathrm{N}_{\text {mic }}$ were calculated as the differences between $\mathrm{C}$ and $\mathrm{N}$ contents in fumigated and non-fumigated samples, using correction factors of 0.3 [30] and 0.54 [31], respectively.

Microbial activity was characterised as potential aerobic and anaerobic $\mathrm{CO}_{2}$ production and potential anaerobic $\mathrm{CH}_{4}$ production under laboratory conditions for a period of 50 days at $10^{\circ} \mathrm{C}$. Homogenised peat $(10 \mathrm{~g})$ was placed in a $120 \mathrm{~mL}$ glass bottle, which was tightly closed with a rubber stopper. The aerobic samples were ventilated regularly. In the anaerobic treatments, the headspace was flushed with helium and the bottles were kept tightly closed for the whole incubation period. Gas in the headspace was sampled each week and the concentrations of $\mathrm{CO}_{2}$ and $\mathrm{CH}_{4}$ were determined by gas chromatography (HP 6850 and $\mathrm{HP}$ 6890 gas chromatographs, Agilent, USA). Rates of $\mathrm{CO}_{2}$ and $\mathrm{CH}_{4}$ production were calculated as averages for the whole incubation period.

\subsection{Potential enzyme activity}

Potential activities of extracellular hydrolytic enzymes were determined by microplate fluorometric assays under standardised laboratory conditions [32] with some modifications [33]. Briefly, $1 \mathrm{~g}$ of soil was suspended in $100 \mathrm{~mL}$ of distilled water and sonicated $(35 \mathrm{kHz})$ for 4 min to disrupt the soil particles. $200 \mu \mathrm{L}$ of the soil suspension was then added to $50 \mu \mathrm{L}$ 
of a methylumbelliferyl (MUF) substrate solution for $\beta$-glucosidase, exocellulase (cellobiohydrolase), phosphatase and chitinase ( $\mathrm{N}$-acetyl-glucosaminidase) determination or to $50 \mu \mathrm{L}$ of a 7-aminomethyl-4-coumarin (AMC) substrate solution for leucineaminopeptidase determination. Three concentrations of each fluorogenic substrate were tested (50, 100 and $300 \mu \mathrm{M})$ and the one with the highest enzymatic activity was selected. Plates were incubated at $20^{\circ} \mathrm{C}$ for $120 \mathrm{~min}$. Fluorescence was quantified at an excitation wavelength of $365 \mathrm{~nm}$ and emission wavelength of $450 \mathrm{~nm}$ using an Infinite F200 microplate reader (TECAN, Germany). Activities of the oxidative enzymes phenoloxidase and peroxidase were measured photometrically at $460 \mathrm{~nm}$ using L-DOPA as the substrate according to Kaiser et al. [34].

Activities of oxidative enzymes (Eox) were added up to characterise the soil potential to degrade lignin-like compounds. Hydrolytic enzymes $\left(\mathrm{E}_{\mathrm{HYDR}}\right)$ were divided into the following categories: $\beta$-glucosidase and cellobiohydrolase activities represent $\mathrm{C}$ acquisition enzymes, leucine-aminopeptidase and chitinase activities enzymes involved in $\mathrm{C}$ and $\mathrm{N}$ acquisition, and phosphatase activity $\mathrm{P}$ acquisition.

\subsection{SOM quality: sequential chemical fractionation and IR spectroscopy}

Chemical fractionation was applied to separate soil organic matter (SOM) pools according to their mobility and potential availability [35]. Four fractions were separated by sequential extraction of samples with cold water (CW), hot water (HW), hot acid (HAE), leaving behind a non-hydrolysable residue (NON). Briefly, $5 \mathrm{~g}$ of fresh subsample was extracted by shaking with $20 \mathrm{ml}$ of deionised water for $1 \mathrm{~h}$ at room temperature. The soil solution was then centrifuged at $4500 \mathrm{x} \mathrm{g}$ for $20 \mathrm{~min}$ and the supernatant filtered through a glass-fibre filter $(0.45 \mu \mathrm{m})$ and frozen [36]. The same sample was re-extracted with $20 \mathrm{~mL}$ of hot water $\left(80^{\circ} \mathrm{C}\right)$ for $18 \mathrm{~h}$, followed by centrifugation, filtration and freezing of the filtrate. 
Both water extracts were then analysed for total $\mathrm{C}$ and $\mathrm{N}$ content with LiquiTOCII (Elementar, Germany), and the $\mathrm{CW}$ extract was additionally analysed for soluble reactive phosphorus (SRP) with a flow-injection analyser (FIA Lachat QC8500, Lachat Instruments, USA). Acid hydrolysis was then applied to the dried and milled peat samples $(0.1 \mathrm{~g}$ of sample $+10 \mathrm{~mL}$ of $6 \mathrm{M} \mathrm{HCl})$ at $110^{\circ} \mathrm{C}$ for $18 \mathrm{~h}$ according to Leavitt et al. [37]. The non-hydrolysable soil fraction was dried and analysed for total $\mathrm{C}$ and $\mathrm{N}$ contents and weight loss. The $\mathrm{C}$ and $\mathrm{N}$ content of the HAE fraction was calculated as the difference between the $\mathrm{C}$ and $\mathrm{N}$ content of the NON fraction and the sum of the $\mathrm{C}$ and $\mathrm{N}$ contents of both water extracts.

The chemical composition of SOM was assessed using infrared spectroscopy. Infrared spectra were obtained with a Bruker VERTEX 70 series FTIR (Fourier Transform InfraRed) spectrometer (Bruker Optics, Germany) equipped with a horizontal attenuated total reflectance (ATR) sampling accessory. Freeze-dried and powdered soil samples were loaded directly on the ATR crystal and a MIRacle high-pressure digital clamp was used to achieve even distribution and good contact between sample and crystal. Each spectrum consisted of 65 averaged absorbance measurements between 4000 and $650 \mathrm{~cm}^{-1}$, with a resolution of 4 $\mathrm{cm}^{-1}$. Differences in the amplitude and baseline between different runs (replicate samples) were corrected by standard normal variate transformation and second derivative using Unscrambler software (CAMO, Norway).

\subsection{Statistics}

The differences between the differently managed sites (pristine, drained, restored) for each biogeochemical variable of peat were tested within each peatland type (BOG and SSF) and layer (upper 0-10 $\mathrm{cm}$ and lower 10-30 cm) using one-way ANOVA followed by the posthoc Tukey test when significant effects were detected. The overall effect of management and 
layer on each biogeochemical variable was tested separately for each peatland type using factorial ANOVA (STATISTICA 11, Stat Soft).

Principal component analysis (PCA) was used to evaluate the similarity of vegetation between the pristine, drained and restored sites. The effect of management on vegetation cover of different plant functional groups was also tested by one-way ANOVA followed by the post-hoc Tukey test when effects were significant. PCA was also used to distinguish the effect of management and peat layer on selected biogeochemical properties of peat and SOM quality (Canoco 5). The data were standardised by species and log-transformed.

The percentage of variation in infrared spectroscopy data explained by management and peat layer was analysed by redundancy analysis (RDA). Calibration models for quantification of several SOM quality parameters from infrared spectra were built using partial least squares (PLS) regression. The models use spectral absorbances at all wavelengths as the $X$-matrix, and a chemical property (here values from chemical fractionation) as the $Y$-variable. The predictive abilities of the models were tested using full cross-validation, which systematically removes one sample from the dataset, establishes a model with the remaining samples, and uses that model to predict the value of the $Y$-variable for the removed sample. This process continues with all samples successively being removed from the dataset until all the samples are predicted. Therefore, the predictions are independent as they are based on regression models that do not include the predicted data. The $\mathrm{r}^{2}$ values, root mean square error (RMSE) of calibration and prediction were used for estimating the accuracy of the models. RMSE indicates the error of calibration/prediction in the same units as the $Y$-variable (lab-measured values from chemical fractionation, $\mathrm{mg} \mathrm{g}^{-1}$ ). 


\section{Results}

\subsection{Effect of drainage and rewetting on water table and vegetation}

The average water table position (WT) was $-8.5 \pm 2.3 \mathrm{~cm}$ and $-9 \pm 5.5 \mathrm{~cm}$ in the pristine peatland types BOGp and SSFp, respectively. Average WT in BOGd and SSFd $(-20 \pm 8 \mathrm{~cm}$ and $-34 \pm 13 \mathrm{~cm}$, respectively) was significantly lower than in the pristine sites $(p<0.01)$ and fluctuated more strongly during the season. Rewetting increased and stabilised WT in both BOGr and SSFr $(-12 \pm 4.6 \mathrm{~cm}$ and $-14 \pm 7.7 \mathrm{~cm}$, respectively) compared with the drained sites $(p<0.01)$

The overall composition of the plant community did not differ between the management types; however, some plant functional groups (sedges, forest mosses and Sphagnum mosses) varied in their cover between the management types. The most distinctive differences were found between the pristine sites and the other two treatments, with the restored sites already showing some dissimilarity to the drained sites, clustering closer to the pristine sites (Fig. 1). Drainage significantly decreased the cover of sedges in both BOGd and SSFd compared to the pristine sites, while dwarf shrubs became dominant (Fig. 2). Similarly, Sphagnum mosses, which were the dominant species of the floor layer in BOGp and SSFp, retreated after drainage in favour of forest mosses. The rewetted sites showed partial recovery of the original vegetation. The SSF sites showed a more dramatic vegetation shift after drainage as well as a more pronounced return after rewetting than the BOG sites (Fig. 1, 2).

\subsection{Effect of drainage and rewetting on physicochemical properties of peat}

The effect of drainage and rewetting on the basic physicochemical properties of peat varied between the peatland types. In BOG, management did not affect any of the basic peat properties ( $\mathrm{pH}$, bulk density, $\mathrm{C}_{\mathrm{TOT}}, \mathrm{P}_{\mathrm{TOT}}, \mathrm{C}: \mathrm{P}$ ) except for $\mathrm{N}_{\mathrm{TOT}}$, which was lower in BOGd, as reflected in the increased peat $\mathrm{C}: \mathrm{N}$ ratio (Table 1). Almost all basic peat parameters differed 
between the upper and lower peat layers at the BOG sites. By contrast, the SSF sites did not show any clear stratification in peat characteristics with depth, except for a significantly lower $\mathrm{P}$ content in the lower than in the upper peat layer. However, most of the SSF peat parameters were significantly influenced by management, except for the peat $\mathrm{C}$ concentration and its $\mathrm{N}: \mathrm{P}$ ratio (Table 1). SSFd had more acidic peat with higher bulk density, containing more $\mathrm{N}$ and $\mathrm{P}$, than SSFp, and thus significantly lower C:N:P ratios. Soil $\mathrm{pH}$ in SSFr increased to the level of SSFp peat, while peat bulk density and nutrient concentrations remained high and comparable with SSFd.

\subsection{Effect of drainage and rewetting on microbial biomass, respiration and enzyme activity}

In contrast to the basic peat properties, soil microbial biomass and microbial respiration were strongly stratified with depth in both peatland types, being significantly higher in the upper than the lower peat layer (Table 2). Generally, although microbial biomass was comparable between BOG and SSF, the nutrient-richer SSF showed higher potential aerobic respiration, $\mathrm{CH}_{4}$ production and oxidative potential (Table 2). Interestingly, the hydrolytic enzymes were more active in BOG.

The microbial biomass was significantly influenced by management and responded generally in a similar way in both peatland types. $\mathrm{C}_{\text {mic }}$ was the highest in both BOGp and SSFp and significantly decreased in the drained sites (Table 2). BOGr showed equal $\mathrm{C}_{\text {mic }}$

content as BOGp, while $\mathrm{C}_{\text {mic }}$ in SSFr remained low. Similar trends were observed for $\mathrm{N}_{\text {mic }}$, but the effect of management was not significant.

The anaerobic $\mathrm{CO}_{2}$ production rate was significantly reduced by drainage in both BOGd (in the lower layer) and SSFd (in both layers), with a more pronounced decrease in $\mathrm{SSFd} . \mathrm{CH}_{4}$ production was significantly reduced by drainage in SSFd only and not in BOGd (Table 2). In 
all cases, the anaerobic $\mathrm{CO}_{2}$ and $\mathrm{CH}_{4}$ production rates were lower on restored compared to pristine sites.

Management influences the ratio of $\mathrm{C}$-acquiring to P-acquiring enzymes. The majority of hydrolytic activity was comprised of P-acquiring enzymes (75-90\%) in both peatland types, independently of management. Still, the relative contribution of P-acquiring enzymes significantly decreased in favour of C-acquiring enzymes in both BOGd and SSFd compared to pristine sites, with restored sites showing intermediate values.

Principal component analysis (PCA) based on the biogeochemical peat parameters and microbial characteristics confirmed the dominant effect of peat layer over the effect of management (Fig. 3a, b). Samples from the upper and lower layers were clearly separated along the first axis, which explained most of the variability between the samples $(64.3 \%$ for BOG; $49.5 \%$ for SSF). The second axis, representing the effect of management, explained less than $20 \%$ of the variability in the samples, but the effect of drainage was still detectable. Samples from BOGd were separated from BOGp in both layers, reflecting decreased microbial biomass and activity (Fig. 3a), while BOGr was intermediate. The samples from SSFp and SSFd were separated along the second axis, with the SSFd samples located in the lower part of the PCA diagram, reflecting increased bulk density and nutrient concentrations (Fig. 3b). The SSFr samples approached the SSFp samples in their biogeochemical and microbial properties.

\subsection{SOM quality}

SOM quality, based on chemical fractionation, was comparable between the two peatland types. Generally, CW, the most labile fraction, formed the smallest portion of SOM (about $0.3 \%$ for $\mathrm{C}$ and $0.4 \%$ for $\mathrm{N}$ ), followed by the HW fraction representing about $3 \%$ of $\mathrm{C}$ and $\mathrm{N}$ bound in SOM. The HAE fraction contained about $30-40 \%$ of $\mathrm{C}$ and ca. $80 \%$ of $\mathrm{N}$ bound in 
$\mathrm{SOM}$ and thus this fraction was characterised by the lowest $\mathrm{C} / \mathrm{N}$ ratio (12-22) of all SOM fractions. The most recalcitrant NON fraction contained about $60 \%$ of C and less than $20 \%$ of $\mathrm{N}$ bound in SOM; its $\mathrm{C} / \mathrm{N}$ molar ratio exceeded 100, being the highest of the SOM fractions.

Between-layer differences were significant for most fractions in BOG (Table 3). The lower BOG layer was enriched in CW C, N and SRP while the upper BOG layer contained more HAE N and NON N. Such differences were not found in SSF, where the upper layer had higher contents of HW C and N and lower contents of NON C and N than the lower layer.

The effect of management was generally similar in both peatland sites; the NON fraction increased and the HAE fraction decreased in size on drained compared to pristine sites, with the effect being more pronounced in the upper layer (Table 3). The PCA diagram of BOG samples shows the dominant effect of peat layer on SOM quality and the weaker effect of management (Fig. 3c). The samples from different BOG layers were separated along the first axis, which explained $43.1 \%$ of the variability in the data (Fig. 3c). However, the effect of management on SOM quality was reflected most clearly in the changing content of HAE C and HW $\mathrm{C}$ along the second axis, which explained $25.6 \%$ of the variability in the data. By contrast, the PCA diagram of SSF samples shows a significant effect of drainage on SOM quality (Fig. 3d). The samples from both layers in the SSFd and SSFr sites were separated from the SSFp samples, which reflected the changing content of the recalcitrant NON fraction. The effect of soil layer on SOM quality in SSF was also evident, but did not overrule the effect of management.

\subsection{Infrared spectroscopy of SOM}

The results of infrared spectroscopy of SOM correspond to the results obtained by chemical fractionation and confirmed the distinct responses of the two peatland types to management (Fig. 3e, f). In the case of BOG, the main portion of variation in the peat infrared 
spectra was explained by differences between the peat layers $(25 \%)$ with minimal effect of management (3\%). By contrast, variation of SSF peat spectral data was explained by management $(23 \%)$ while the differences between the layers were negligible. SOM from SSFd and SSFr was enriched in recalcitrant compounds, such as lignin-like structures and aromatic and aliphatic compounds, while they contained lower amounts of polysaccharides and cellulose compared to SSFp (Fig. 3f). In BOG, the upper layer was enriched in recalcitrant compounds compared with the lower layer (Fig. 3e).

SOM quality parameters were quantified with good accuracy using infrared spectroscopybased regression models (Fig. 4). RMSE of prediction was only $2-7 \%$ of the average reference values for $\mathrm{C}$ and $6-14 \%$ of the average reference values for $\mathrm{N}$.

\section{Discussion}

\subsection{Drainage effects on peat and microbial properties in bogs and spruce swamp forests}

Long-term drainage of the peatlands caused substantial changes in SOM quality. Peat in the drained sites had a higher bulk density and a larger proportion of the recalcitrant fraction than in the pristine sites. These differences are a consequence of enhanced organic matter decomposition following aeration of the upper peat layer, which leads to depletion of labile $\mathrm{C}$ forms and peat compaction. This change in organic matter quality was further intensified by a shift in vegetation structure towards shrubs and trees, which supply the soil with litter that decomposes slowly, likely due to its high content of lignin-like compounds [38, 39]. In contrast to the bogs, the SSF sites experienced additional substantial changes to the soil after drainage, such as significant acidification and an increase in $\mathrm{N}$ and $\mathrm{P}$ contents in the newlyformed SOM in the upper $10 \mathrm{~cm}$ of soil. The more sensitive response to drainage of SSF compared with bogs is likely connected with its originally higher $\mathrm{pH}$, trophic status and peat quality, which is related to the large contribution of nutrient-richer and more degradable sedge 
litter [38]. Such peat is more susceptible to decomposition after drainage. The increased nutrient availability stimulates faster spreading of new vegetation and a more pronounced change in its composition as well as in the structure of the soil microbial community $[8,10$, $13,15]$.

The higher recalcitrance and acidity of the SOM in the long-term drained sites is known to limit microbial activity and diversity $[8,11,22,40]$. We identified a decrease in soil microbial biomass $\mathrm{C}$ and in anaerobic $\mathrm{CO}_{2}$ production as the most sensitive microbial indicators of peatland disturbance by drainage. These factors were consistent for both bogs and SSFs. The potential $\mathrm{CH}_{4}$ production, often suggested as a sensitive indicator of peatland degradation [10, 27], significantly decreased only in drained SSF but not in drained bogs. In bogs, the harsh conditions and a shortage of suitable substrates enabled only very low $\mathrm{CH}_{4}$ production even in pristine sites. Similarly, the effect of drainage on enzyme activities was insignificant and inconsistent between the two types of peatlands. While the total activity of hydrolases decreased in drained bogs together with decreasing soil microbial biomass, it tended to increase in drained SSF. Oxidative enzymes also tended to be more active in drained than in pristine SSF, while they were not affected by drainage in bogs. This can be related to the enhanced growth of spruce trees in drained SSF and the accompanying spread of ectomycorrhizal fungi and their enzyme production [41]. Despite the difference between bogs and SSF in drainage effects on hydrolytic enzyme activities, there was a consistent increase in relative investments into $\mathrm{C}$-acquiring enzymes to the detriment of $\mathrm{P}$-acquiring activity in both types of systems.

In summary, our results suggest that the drainage effect on peatland characteristics and functioning is more pronounced in SSF in comparison with the relatively resistant bogs. The changes in the systems were best indicated by increased peat compaction and SOM 
recalcitrance, which were tightly connected with decreased soil microbial biomass and anaerobic respiration and enhanced relative investment in $\mathrm{C}$-acquiring enzyme activity.

\subsection{Rewetting effect on peat and microbial properties in bogs and SSF}

The functioning of peatlands depends on the fragile connection between water tables and vegetation communities [42]. Our results showed that peatland rewetting effectively initiated the recovery of hydrological conditions characteristic of pristine sites. At our rewetted peatlands, the water table was significantly higher than at the drained sites, but still experienced significant temporal fluctuation. This is because SOM in the long-term drained sites was not able to effectively retain water due to its increased bulk density and decreased

porosity $[8,43]$. Therefore, complete restoration of the original hydrological conditions is expected to occur only once a suitably thick layer of new peat has been accumulated $[44,45]$.

The increase in the water table permitted recolonisation by typical peatland plant species, especially Sphagnum mosses and sedges, and subsequently forced the retreat of dwarf shrubs and die-off of trees that dominated the drained sites. The coverage of Sphagnum and sedges in the rewetted SSF sites doubled within 4 years; this occurred after the previous vegetation description of the same sites by Mastný et al. [29]. However, the Sphagnum cover is still patchy and an accumulation of new peat has not been detected 6-15 years after rewetting. Some studies estimated that two to three decades are needed for the re-establishment of a moss carpet and development of a new functional acrotelm [45-47]. We assume that the regeneration rate of the surface layer in forested drained peatlands may be even slower than in mined peatlands with a bare surface $[45,46,48]$. In fact, the heterogeneous surface of the non-mined peatlands could hinder the development of a Sphagnum carpet and enable longterm survival of the forest species. 
As not enough new organic matter had yet accumulated on the restored sites, we found no significant change in overall SOM quality after rewetting. However, statistical visualisation of SOM quality did already show some dissimilarity between the rewetted and drained sites, with a reduced proportion of recalcitrant compounds especially in the SSFr sites reflecting input of fresh litter. In restored SSF, with the rise in water table $\mathrm{pH}$ increased to the level of the pristine sites, indicating a return of prevailing anaerobic conditions. Despite the absence of pronounced changes in SOM quality, changes in microbial characteristics were detected in rewetted sites. In bogs, soil microbial biomass reached the levels characteristic for pristine sites within 6-15 years after rewetting. Similar observations exist for restored cutaway bogs $[22,23]$. However, the same was not the case in restored SSF, where the microbial biomass remained as low as in the drained sites. This lack of response is likely due to the stronger changes at the SSF sites and more time may be needed to approach the original state. The spreading vegetation provided microbes with easily available $\mathrm{C}$ by root exudation and fresh litter, which supported aerobic and anaerobic $\mathrm{CO}_{2}$ production as well as methanogenesis. The enhancement of methanogenesis is another indicator of the return of stable anaerobic conditions, besides the increased $\mathrm{pH}$. The parameters of microbial activity, such as anaerobic respiration and methanogenesis, followed the trend that had been detected in the previous study by Mastný et al. [29], in which these authors showed that the values gradually began approaching the pristine level. The enhancement of $\mathrm{C}$ availability in the restored systems was also reflected in the $\mathrm{C}: \mathrm{P}$ stoichiometry of enzyme activity moving towards the situation in the pristine sites.

In summary, we found that rewetting initiated the spread of typical peatland plant species, which is a necessary prerequisite for the successful re-establishment of high water retention capability, organic matter accumulation and anaerobic microbial processes that are characteristic for the pristine forms of these ecosystems [3]. Plant recolonisation of rewetted 
peatlands is a slow process, hence the lack of any significant changes in the quality of bulk SOM during the 6-15 years following rewetting. However, the stimulation of microbial biomass and its respiration indicated an enhanced input of easily available organic matter by the vegetation and the success of the restoration process.

\subsection{SOM quality analysis with infrared spectroscopy}

When comparing differences in SOM quality between peat from pristine, drained and rewetted sites, fast and low-cost infrared spectroscopy gave results comparable to those obtained from traditional chemical fractionation. PLS regression models enabled quantification of SOM quality parameters with good accuracy. These results are all in line with earlier studies where infrared spectroscopy, both in the mid- and near-infrared ranges, has been successfully tested or used for evaluation of SOM quality of peat and for monitoring of restoration progress in peatland ecosystems [25, 29, 49, 50].

\section{Conclusions - Suggested indicators of restoration progress in peatlands}

A rise of the water table and proliferation of typical peatland vegetation are the first indicators that mechanistic functioning of these systems is being restored. Recovery of belowground ecosystem characteristics may take longer and should be useful for the

evaluation of the success in overall restoration of natural peatland functioning, including microbial activity and peat decomposition dynamics.

Based on our results, we suggest that soil microbial biomass $\mathrm{C}$ and anaerobic $\mathrm{CO}_{2}$ production are universal early indicators of belowground changes connected with the input of new, easily degradable plant-derived organic matter. Additionally, in minerotrophic peatlands increasing $\mathrm{pH}$ and $\mathrm{CH}_{4}$ production are early and sensitive indicators of belowground changes. We cannot recommend enzyme activities as indicators of change, as suggested by Nurulita et 
al. [28] who worked in burned tropical peatlands. We showed that the responses of enzymes in general and of phosphatase in particular are ambiguous, possibly small, and in our case also system-dependent.

Using only microbial indicators is not sufficient to evaluate the restoration success of peatlands or the recovery of their functioning as $\mathrm{C}$ sinks. Full restoration of peat-forming vegetation and peat bulk density can be used as indicators of the long-term progress of restoration.

\section{Acknowledgements}

We thank Ondra Žampach for assistance in the field and Daniel Vaněk and Terezia Ř́hová for their help in the laboratory. We thank Dr. G. Kerstiens for language correction. This work was supported by the Czech Science Foundation [grant number 14-17403P] and the Academy of Finland [grant number 1259190, for PS]. The work was supported by the European Regional Development Fund, Project "Research of key soil-water ecosystem interactions at the SoWa Research Infrastructure" (No. CZ.02.1.01/0.0/0.0/16_013/0001782).

\section{References}

[1] J. Limpens, F. Berendse, C. Blodau, J.G. Canadell, C. Freeman, J. Holden, N. Roulet, H. Rydin, G. Schaepman-Strub, Peatlands and the carbon cycle: from local processes to global implications a synthesis (vol 5, pg 1475, 2008), Biogeosciences, 5 (2008) 1739-1739.

[2] L.E. Parry, J. Holden, P.J. Chapman, Restoration of blanket peatlands, J Environ Manage, 133 (2014) 193-205.

[3] D. Moreno-Mateos, M.E. Power, F.A. Comin, R. Yockteng, Structural and Functional Loss in Restored Wetland Ecosystems, Plos Biol, 10 (2012).

[4] S. Chapman, A. Buttler, A. Francez, F. Laggoun-Defarge, H. Vasander, M. Schloter, J. Combe, P. Grosvernier, H. Harms, D. Epron, D. Gilbert, E. Mitchell, Exploitation of northern peatlands and biodiversity maintenance: a conflict between economy and ecology, Front Ecol Environ, 1 (2003) 525-532. 
[5] J. Holden, P.J. Chapman, J.C. Labadz, Artificial drainage of peatlands: hydrological and hydrochemical process and wetland restoration, Prog Phys Geog, 28 (2004) 95-123.

[6] J.M. Waddington, J.S. Price, Effect of peatland drainage, harvesting, and restoration on atmospheric water and carbon exchange, Phys Geogr, 21 (2000) 433-451.

[7] P. Straková, J. Anttila, P. Spetz, V. Kitunen, T. Tapanila, R. Laiho, Litter quality and its response to water level drawdown in boreal peatlands at plant species and community level, Plant Soil, 335 (2010) 501-520.

[8] M.L. Macrae, K.J. Devito, M. Strack, J.M. Waddington, Effect of water table drawdown on peatland nutrient dynamics: implications for climate change, Biogeochemistry, 112 (2013) 661-676.

[9] K. Kalbitz, Properties of organic matter in soil solution in a German fen area as dependent on land use and depth, Geoderma, 104 (2001) 203-214.

[10] Z. Urbanová, J. Bárta, Effects of long-term drainage on microbial community composition vary between peatland types, Soil Biol Biochem, 92 (2016) 16-26.

[11] C. Blodau, M. Siems, Drainage-induced forest growth alters belowground carbon biogeochemistry in the Mer Bleue bog, Canada, Biogeochemistry, 107 (2012) 107-123.

[12] M. Croft, L. Rochefort, C.J. Beauchamp, Vacuum-extraction of peatlands disturbs bacterial population and microbial biomass carbon, Appl Soil Ecol, 18 (2001) 1-12.

[13] K. Minkkinen, H. Vasander, S. Jauhiainen, M. Karsisto, J. Laine, Post-drainage changes in vegetation composition and carbon balance in Lakkasuo mire, Central Finland, Plant Soil, 207 (1999) 107-120.

[14] K. Peltoniemi, H. Fritze, R. Laiho, Response of fungal and actinobacterial communities to water-level drawdown in boreal peatland sites, Soil Biol Biochem, 41 (2009) 1902-1914.

[15] V.M. Komulainen, E.S. Tuittila, H. Vasander, J. Laine, Restoration of drained peatlands in southern Finland: initial effects on vegetation change and $\mathrm{CO} 2$ balance, J Appl Ecol, 36 (1999) 634-648.

[16] L. Maanavilja, K. Aapala, T. Haapalehto, J.S. Kotiaho, E.S. Tuittila, Impact of drainage and hydrological restoration on vegetation structure in boreal spruce swamp forests, Forest Ecol Manag, 330 (2014) 115-125.

[17] S. Jauhiainen, R. Laiho, H. Vasander, Ecohydrological and vegetational changes in a restored bog and fen, Ann Bot Fenn, 39 (2002) 185-199.

[18] T. Kuuluvainen, K. Aapala, P. Ahlroth, M. Kuusinen, T. Lindholm, T. Sallantaus, J. Siitonen, H. Tukia, Principles of ecological restoration of boreal forested ecosystems: Finland as an example, Silva Fenn, 36 (2002) 409-422. 
[19] R. Andersen, C. Wells, M. Macrae, J. Price, Nutrient mineralisation and microbial functional diversity in a restored bog approach natural conditions 10 years post restoration, Soil Biol Biochem, 64 (2013) 37-47.

[20] S. Kareksela, T. Haapalehto, R. Juutinen, R. Matilainen, T. Tahvanainen, J.S. Kotiaho, Fighting carbon loss of degraded peatlands by jump-starting ecosystem functioning with ecological restoration, Sci Total Environ, 537 (2015) 268-276.

[21] A.J. Francez, S. Gogo, N. Josselin, Distribution of potential CO2 and CH4 productions, denitrification and microbial biomass $\mathrm{C}$ and $\mathrm{N}$ in the profile of a restored peatland in Brittany (France), Eur J Soil Biol, 36 (2000) 161-168.

[22] R. Andersen, A.-J. Francez, L. Rochefort, The physicochemical and microbiological status of a restored bog in Québec: Identification of relevant criteria to monitor success, Soil Biology and Biochemistry, 38 (2006) 1375-1387.

[23] N. Basiliko, C. Blodau, C. Roehm, P. Bengtson, T.R. Moore, Regulation of Decomposition and Methane Dynamics across Natural, Commercially Mined, and Restored Northern Peatlands, Ecosystems, 10 (2007) 1148-1165.

[24] S. Glatzel, N. Basiliko, T. Moore, Carbon dioxide and methane production potentials of peats from natural, harvested, and restored sites, eastern Quebec, Canada, Wetlands, 24 (2004) 261-267.

[25] R.R.E. Artz, S.J. Chapman, A.H. Jean Robertson, J.M. Potts, F. Laggoun-Défarge, S. Gogo, L. Comont, J.-R. Disnar, A.-J. Francez, FTIR spectroscopy can be used as a screening tool for organic matter quality in regenerating cutover peatlands, Soil Biology and Biochemistry, 40 (2008) 515-527.

[26] R.R.E. Artz, S.J. Chapman, A. Siegenthaler, E.A.D. Mitchell, A. Buttler, E. Bortoluzzi, D. Gilbert, M. Yli-Petays, H. Vasander, A.-J. Francez, Functional microbial diversity in regenerating cutover peatlands responds to vegetation succession, J Appl Ecol, 45 (2008) 1799-1809.

[27] K.I.M. Yrjälä, T. Tuomivirta, H. Juottonen, A. Putkinen, K. Lappi, E.-S. Tuittila, T. PenttilÄ, K. Minkkinen, J. Laine, K. Peltoniemi, H. Fritze, CH4 production and oxidation processes in a boreal fen ecosystem after long-term water table drawdown, Global Change Biol, 17 (2011) 1311-1320.

[28] Y. Nurulita, E.M. Adetutu, H. Gunawan, D. Zul, A.S. Ball, Restoration of tropical peat soils: The application of soil microbiology for monitoring the success of the restoration process, Agr Ecosyst Environ, 216 (2016) 293-303. 
[29] J. Mastný, Z. Urbanová, E. Kaštovská, P. Straková, H. Šantrůčková, K.R. Edwards, T. Picek, Soil organic matter quality and microbial activities in spruce swamp forests affected by drainage and water regime restoration, Soil Use Manage, 32 (2016) 200-209.

[30] E.D. Vance, P.C. Brookes, D.S. Jenkinson, An Extraction Method for Measuring Soil Microbial Biomass-C, Soil Biol Biochem, 19 (1987) 703-707.

[31] P.C. Brookes, J.F. Kragt, D.S. Powlson, D.S. Jenkinson, Chloroform Fumigation and the Release of Soil-Nitrogen - the Effects of Fumigation Time and Temperature, Soil Biol Biochem, 17 (1985) 831-835.

[32] M.C. Marx, M. Wood, S.C. Jarvis, A microplate fluorimetric assay for the study of enzyme diversity in soils, Soil Biol Biochem, 33 (2001) 1633-1640.

[33] J. Bárta, P. Šlajsová, K. Tahovská, T. Picek, H. Šantrůčková, Different temperature sensitivity and kinetics of soil enzymes indicate seasonal shifts in $\mathrm{C}, \mathrm{N}$ and $\mathrm{P}$ nutrient stoichiometry in acid forest soil, Biogeochemistry, 117 (2014) 525-537.

[34] C. Kaiser, M. Koranda, B. Kitzler, L. Fuchslueger, J. Schnecker, P. Schweiger, F. Rasche, S. Zechmeister-Boltenstern, A. Sessitsch, A. Richter, Belowground carbon allocation by trees drives seasonal patterns of extracellular enzyme activities by altering microbial community composition in a beech forest soil, New Phytol, 187 (2010) 843-858.

[35] E. Uhlířová, H. Šantrůčková, S.P. Davidov, Quality and potential biodegradability of soil organic matter preserved in permafrost of Siberian tussock tundra, Soil Biol Biochem, 39 (2007) 1978-1989.

[36] G. Sparling, M. Vojvodic-Vukovic, L.A. Schipper, Hot-water-soluble C as a simple measure of labile soil organic matter: the relationship with microbial biomass C, Soil Biol Biochem, 30 (1998) 1469-1472.

[37] S.W. Leavitt, R.F. Follett, E.A. Paul, Estimation of slow- and fast-cycling soil organic carbon pools from 6N HCl hydrolysis, Radiocarbon, 38 (1996) 231-239.

[38] T.R. Moore, J.L. Bubier, L. Bledzki, Litter Decomposition in Temperate Peatland Ecosystems: The Effect of Substrate and Site, Ecosystems, 10 (2007) 949-963.

[39] R. Laiho, H. Vasander, T. Penttila, J. Laine, Dynamics of plant-mediated organic matter and nutrient cycling following water-level drawdown in boreal peatlands, Global Biogeochem Cy, 17 (2003).

[40] K. Peltoniemi, P. Straková, H. Fritze, P.A. Iráizoz, T. Pennanen, R. Laiho, How waterlevel drawdown modifies litter-decomposing fungal and actinobacterial communities in boreal peatlands, Soil Biology and Biochemistry, 51 (2012) 20-34. 
[41] P.E. Courty, A. Franc, J. Garbaye, Temporal and functional pattern of secreted enzyme activities in an ectomycorrhizal community, Soil Biol Biochem, 42 (2010) 2022-2025.

[42] B.D. Wheeler, M.C.F. Proctor, Ecological gradients, subdivisions and terminology of north-west European mires, J Ecol, 88 (2000) 187-203.

[43] J.S. Price, S.M. Schlotzhauer, Importance of shrinkage and compression in determining water storage changes in peat: the case of a mined peatland, Hydrol Process, 13 (1999) 25912601.

[44] J.S. Price, G.S. Whitehead, Developing hydrologic thresholds for Sphagnum recolonization on an abandoned cutover bog, Wetlands, 21 (2001) 32-40.

[45] M. Lucchese, J.M. Waddington, M. Poulin, R. Pouliot, L. Rochefort, M. Strack, Organic matter accumulation in a restored peatland: Evaluating restoration success, Ecol Eng, 36 (2010) 482-488.

[46] L. Rochefort, F. Quinty, S. Campeau, K. Johnson, T. Malterer, North American approach to the restoration of Sphagnum dominated peatlands, Wetl Ecol Manag, 11 (2003) 3-20.

[47] L. Rochefort, F. Isselin-Nondedeu, S. Boudreau, M. Poulin, Comparing survey methods for monitoring vegetation change through time in a restored peatland, Wetl Ecol Manag, 21 (2013) 71-85.

[48] E.S. Tuittila, H. Vasander, J. Laine, Impact of rewetting on the vegetation of a cut-away peatland, Appl Veg Sci, 3 (2000) 205-212.

[49] S.J. Chapman, C.D. Campbell, A.R. Fraser, G. Puri, FTIR spectroscopy of peat in and bordering Scots pine woodland: relationship with chemical and biological properties, Soil Biol Biochem, 33 (2001) 1193-1200.

[50] D.J.M. Hayes, M.H.B. Hayes, J.J. Leahy, Analysis of the lignocellulosic components of peat samples with development of near infrared spectroscopy models for rapid quantitative predictions, Fuel, 150 (2015) 261-268. 
Table 1. Basic physical (bulk density) and chemical $(\mathrm{pH}$; total $\mathrm{C}, \mathrm{N}$ and $\mathrm{P}$ content and their stoichiometric ratios) properties of peat from the upper $(0-10 \mathrm{~cm})$ and lower $(10-30 \mathrm{~cm}$ ) soil layers in pristine, restored and drained BOG and SSF (mean; $n=12 ; \pm S D$ ). Different letters indicate the significant differences in particular characteristics among differently managed sites within a given soil layer $(p<0.05)$. The results of factorial ANOVA with management $(M)$ and layer (L) as categorical predictors are shown $\left(F\right.$ value); asterisks show the different levels of significance: ${ }^{*} p<0.05,{ }^{* *} p<0.01,{ }^{* * *} p<0.001$.

\begin{tabular}{|c|c|c|c|c|c|c|c|c|c|c|c|c|c|}
\hline & \multirow[b]{2}{*}{ Layer $(\mathrm{cm})$} & \multicolumn{3}{|c|}{ BOG } & \multicolumn{3}{|c|}{ Statistics } & \multicolumn{3}{|c|}{ SSF } & \multicolumn{3}{|c|}{ Statistics } \\
\hline & & Pristine & Restored & Drained & & $\mathrm{M}$ & $\mathrm{L}$ & Pristine & Restored & Drained & & M & $\mathrm{L}$ \\
\hline \multirow[t]{2}{*}{$\mathrm{pH}$} & $0-10$ & $3.95 \pm 0.05$ & $3.91 \pm 0.18$ & $3.96 \pm 0.12$ & aaa & n.s. & n.s. & $4.01 \pm 0.29$ & $4.10 \pm 0.17$ & $3.78 \pm 0.13$ & $a \mathrm{ab}$ & $13.2^{* * *}$ & n.s. \\
\hline & $10-30$ & $3.93 \pm 0.07$ & $3.94 \pm 0.08$ & $4.07 \pm 0.27$ & aaa & & & $4.20 \pm 0.21$ & $4.08 \pm 0.25$ & $3.85 \pm 0.18$ & $a \mathrm{ab} b$ & & \\
\hline \multirow[t]{2}{*}{ bulk density $\left(\mathrm{g} \mathrm{cm}^{-3}\right)$} & $0-10$ & $0.07 \pm 0.02$ & $0.10 \pm 0.02$ & $0.09 \pm 0.03$ & $a b a b$ & n.s. & $18.7^{* * *}$ & $0.05 \pm 0.03$ & $0.11 \pm 0.09$ & $0.12 \pm 0.03$ & $a b b$ & $8.87 * * *$ & n.s. \\
\hline & $10-30$ & $0.06 \pm 0.02$ & $0.06 \pm 0.01$ & $0.07 \pm 0.03$ & aaa & & & $0.06 \pm 0.04$ & $0.10 \pm 0.06$ & $0.12 \pm 0.04$ & $a \mathrm{ab} b$ & & \\
\hline \multirow[t]{2}{*}{$\mathrm{C}_{\mathrm{TOT}}(\%)$} & $0-10$ & $48.2 \pm 0.9$ & $48.2 \pm 0.6$ & $48.6 \pm 1.3$ & aaa & n.s. & n.s. & $44.5 \pm 2.0$ & $43.8 \pm 8.5$ & $43.9 \pm 5.1$ & aaa & n.s. & n.s. \\
\hline & $10-30$ & $47.7 \pm 1.0$ & $47.6 \pm 0.6$ & $48.9 \pm 2.5$ & aaa & & & $45.6 \pm 2.3$ & $46.9 \pm 7.0$ & $47.0 \pm 4.3$ & aaa & & \\
\hline \multirow[t]{2}{*}{$\mathrm{N}_{\text {TOT }}(\%)$} & $0-10$ & $1.88 \pm 0.2$ & $1.89 \pm 0.3$ & $1.65 \pm 0.2$ & aaa & $3.24 *$ & $48.5^{* * *}$ & $1.27 \pm 0.3$ & $1.66 \pm 0.4$ & $1.76 \pm 0.3$ & $a b b$ & $6.38^{* *}$ & n.s. \\
\hline & $10-30$ & $1.44 \pm 0.5$ & $1.15 \pm 0.3$ & $1.18 \pm 0.3$ & aaa & & & $1.43 \pm 0.4$ & $1.44 \pm 0.2$ & $1.60 \pm 0.2$ & aaa & & \\
\hline \multirow[t]{2}{*}{$\mathrm{P}_{\text {TOT }}(\%)$} & $0-10$ & $0.07 \pm 0.01$ & $0.07 \pm 0.02$ & $0.07 \pm 0.01$ & aaa & n.s. & $76.3^{* * *}$ & $0.08 \pm 0.02$ & $0.08 \pm 0.01$ & $0.10 \pm 0.03$ & $a a b b$ & $4.79 *$ & $7.55^{* *}$ \\
\hline & $10-30$ & $0.04 \pm 0.01$ & $0.04 \pm 0.01$ & $0.04 \pm 0.02$ & aaa & & & $0.07 \pm 0.02$ & $0.07 \pm 0.03$ & $0.08 \pm 0.02$ & aaa & & \\
\hline \multirow[t]{2}{*}{$\mathrm{C}: \mathrm{N} \mathrm{mol} \mathrm{mol}{ }^{-1}$} & $0-10$ & $30.3 \pm 3.2$ & $30.7 \pm 5.6$ & $35.0 \pm 4.8$ & aaa & $3.77^{*}$ & $50.0 * * *$ & $43.8 \pm 11.2$ & $31.1 \pm 3.0$ & $29.7 \pm 3.8$ & $a b b$ & $9.83^{* * *}$ & n.s. \\
\hline & $10-30$ & $41.5 \pm 9.0$ & $51.2 \pm 12.9$ & $52.0 \pm 14.5$ & aaa & & & $39.3 \pm 8.5$ & $39.0 \pm 8.5$ & $34.5 \pm 4.4$ & aaa & & \\
\hline \multirow[t]{2}{*}{$\mathrm{C}: \mathrm{P}$ mol mol${ }^{-1}$} & $0-10$ & $1883 \pm 283$ & $1807 \pm 514$ & $1908 \pm 219$ & aaa & n.s. & $56.5^{* * *}$ & $1600 \pm 353$ & $1366 \pm 293$ & 1180258 & $a a b b$ & $3.85^{*}$ & $18.3^{* * *}$ \\
\hline & $10-30$ & $3016 \pm 805$ & $3549 \pm 1097$ & $3807 \pm 1481$ & aaa & & & $1910 \pm 442$ & $2146 \pm 856$ & $1626 \pm 462$ & aaa & & \\
\hline \multirow[t]{2}{*}{$\mathrm{N}: \mathrm{P} \mathrm{mol} \mathrm{mol}^{-1}$} & $0-10$ & $62.2 \pm 7.7$ & $58.1 \pm 7.2$ & $55.3 \pm 7.9$ & aaa & n.s. & $35.7^{* * *}$ & $37.5 \pm 7.8$ & $43.8 \pm 7.8$ & $39.8 \pm 7.5$ & aaa & n.s. & $15.7^{* * *}$ \\
\hline & $10-30$ & $73.0 \pm 11.2$ & $68.7 \pm 5.8$ & $71.1 \pm 9.5$ & aaa & & & $48.9 \pm 7.8$ & $52.8 \pm 13.4$ & $46.5 \pm 9.8$ & aaa & & \\
\hline
\end{tabular}


Table 2. Average concentration of microbial biomass $\mathrm{C}$ and $\mathrm{N}$ and their stoichiometric ratio, aerobic and anaerobic $\mathrm{CO}_{2}$ and $\mathrm{CH}_{4}$ potential production $\left(\mathrm{CO}_{2}\right.$ aer, $\mathrm{CO}_{2}$ anaer, $\mathrm{CH}_{4}$ anaer) and sum of potential activities of hydrolytic and oxidative enzymes in the upper $(0-10 \mathrm{~cm})$ and lower $(10-30 \mathrm{~cm})$ soil layers in pristine, restored and drained $B O G$ and SSF (mean; $n=12 ; \pm S D$ ). Hydrolytic enzymatic activity is further divided into four classes and the percentage proportion of $\mathrm{C}, \mathrm{CN}$ and $\mathrm{P}$ gaining enzymes in total hydrolytic enzyme activity is shown. Different letters indicate significant differences in particular characteristics among differently managed sites within a given soil layer $(p<0.05)$. The results of factorial ANOVA with management (M) and layer $(L)$ as categorical predictors are shown ( $F$ value); asterisks show the different levels of significance: ${ }^{*} p<0.05,{ }^{* *} p<0.01,{ }^{* * *} p<0.001$.

\begin{tabular}{|c|c|c|c|c|c|c|c|c|c|c|c|c|c|}
\hline & & \multicolumn{3}{|c|}{ BOG } & \multicolumn{3}{|c|}{ Statistics } & \multicolumn{3}{|c|}{ SSF } & \multicolumn{3}{|c|}{ Statistics } \\
\hline & $\begin{array}{l}\text { Layer } \\
(\mathrm{cm})\end{array}$ & Pristine & Restored & Drained & & M & $\mathrm{L}$ & Pristine & Restored & Drained & & $\mathrm{M}$ & L \\
\hline \multirow{2}{*}{$C_{\text {mic }}\left(\mu \mathrm{g} \mathrm{g}^{-1}\right)$} & $0-10$ & $6610 \pm 1199$ & $5933 \pm 2282$ & $3978 \pm 1892$ & $a a b$ & \multirow{2}{*}{$7.13 * *$} & \multirow{2}{*}{$54.1 * * *$} & $7108 \pm 2602$ & $3596 \pm 1559$ & $4386 \pm 2804$ & $a b b$ & \multirow{2}{*}{$8.18^{* * *}$} & \multirow{2}{*}{$40.7^{* * *}$} \\
\hline & $10-30$ & $2778 \pm 791$ & $2794 \pm 2305$ & $1810 \pm 907$ & aaa & & & 2333. \pm 976 & $1370 \pm 741$ & $2741 \pm 1273$ & $a b a b$ & & \\
\hline \multirow{2}{*}{$N_{\text {mic }}\left(\mu g^{-1}\right)$} & $0-10$ & $343 \pm 89$ & $286 \pm 128$ & 22592 & $a a b b$ & \multirow{2}{*}{ n.s. } & \multirow{2}{*}{$54.8^{* * *}$} & $454 \pm 157$ & $319 \pm 137$ & $342 \pm 158$ & aaa & \multirow{2}{*}{ n.s. } & \multirow{2}{*}{$56.0 * * *$} \\
\hline & $10-30$ & $101 \pm 53$ & $129 \pm 134$ & 9845 & aaa & & & $138 \pm 69$ & $99 \pm 64$ & $207 \pm 104$ & $a b a b$ & & \\
\hline \multirow{2}{*}{$\mathrm{C}_{\text {mic }}: \mathrm{N}_{\text {mic }}\left(\mathrm{mol} \mathrm{mol}^{-1}\right)$} & $0-10$ & $23.3 \pm 4.2$ & $25.2 \pm 5.9$ & $21.9 \pm 7.5$ & aaa & \multirow{2}{*}{$3.95^{*}$} & \multirow{2}{*}{$8.2^{* *}$} & $18.4 \pm 3.1$ & $20.1 \pm 3.4$ & $14.7 \pm 2.5$ & aaa & \multirow[t]{2}{*}{ n.s. } & \multirow[t]{2}{*}{ n.s. } \\
\hline & $10-30$ & $41.4 \pm 22.0$ & $31.8 \pm 14.7$ & $22.6 \pm 7.6$ & $a a b b$ & & & $21.1 \pm 6.5$ & $18.2 \pm 6.8$ & $16.1 \pm 2.6$ & aaa & & \\
\hline \multirow{2}{*}{$\mathrm{CO}_{2} \operatorname{aer}\left(\mu \mathrm{L} \mathrm{CO}_{2} \mathrm{~g}^{-1} \mathrm{~h}^{-1}\right)$} & $0-10$ & $4.87 \pm 2.6$ & $4.18 \pm 1.1$ & $4.0 \pm 1.2$ & aaa & \multirow{2}{*}{ n.s. } & \multirow{2}{*}{$56.2^{* * *}$} & $14.4 \pm .4 .9$ & $17.6 \pm 10.1$ & $10.9 \pm 8.9$ & aaa & \multirow{2}{*}{ n.s. } & \multirow{2}{*}{$29.8 * * *$} \\
\hline & $10-30$ & $2.06 \pm 0.7$ & $1.83 \pm 0.6$ & $1.6 \pm 0.8$ & aaa & & & $7.01 \pm 3.6$ & $5.02 \pm 1.7$ & $5.08 \pm 5.0$ & aaa & & \\
\hline \multirow{2}{*}{$\mathrm{CO}_{2}$ anaer $\left(\mu \mathrm{LCO}_{2} \mathrm{~g}^{-1} \mathrm{~h}^{-1}\right)$} & $0-10$ & $1.87 \pm .0 .6$ & $1.62 \pm .0 .5$ & $1.6 \pm .0 .3$ & aaa & \multirow[t]{2}{*}{$3.29 *$} & \multirow[t]{2}{*}{$78.7^{* * *}$} & $2.90 \pm 0.8$ & $2.23 \pm 0.9$ & $1.51 \pm 0.6$ & $a \mathrm{ab} b$ & \multirow[t]{2}{*}{$12.9 * * *$} & \multirow[t]{2}{*}{$93.7^{* * *}$} \\
\hline & $10-30$ & $1.01 \pm .0 .2$ & $0.72 \pm .0 .2$ & $0.8 \pm .0 .3$ & $a b a b$ & & & $1.07 \pm 0.3$ & $0.76 \pm 0.3$ & $0.69 \pm 0.3$ & $a b b$ & & \\
\hline \multirow{2}{*}{$\mathrm{CH}_{4}$ anaer $\left(\mu \mathrm{LCH} 4 \mathrm{~g}^{-1} \mathrm{~h}^{-1}\right)$} & $0-10$ & $0.024 \pm .0 .03$ & $0.017 \pm .0 .03$ & $0.025 \pm .0 .04$ & aaa & $n c$ & $n c$ & $0.48 \pm 0.3$ & $0.16 \pm 0.3$ & $0.01 \pm 0.02$ & $a b b$ & $12.0 * * *$ & $19.7 * * *$ \\
\hline & $10-30$ & $0.025 \pm .0 .04$ & $0.014 \pm .0 .03$ & $0.003 \pm .0 .01$ & aaa & n.s. & n.s. & $0.05 \pm 0.08$ & $0.00 \pm 0.01$ & $0.00 \pm 0.00$ & aaa & & \\
\hline Sum of hydrolytic enz. & $0-10$ & $1501 \pm 600$ & $1274 \pm 746$ & $993 \pm 716$ & aaa & $331 *$ & $522 * * *$ & $597 \pm 305$ & $791 \pm 369$ & $712 \pm 231$ & aaa & n.s. & $21.2^{* * *}$ \\
\hline activity (nmol g & $10-30$ & $487 \pm 318$ & $349 \pm 181$ & $200 \pm 97$ & $a \mathrm{ab} b$ & & & $420 \pm 225$ & $346 \pm 198$ & $400 \pm 281$ & aaa & & \\
\hline$\%$ c gaining enzymes & $0-10$ & $6.38 \pm 1.7$ & $7.42 \pm 2.2$ & $11.5 \pm 5.4$ & $a a b$ & $13.2 * * *$ & $15.8 * * *$ & $13.0 \pm 5.9$ & $17.8 \pm 3.3$ & $21.5 \pm 12.1$ & $a \mathrm{ab} b$ & $903 * * *$ & $n s$ \\
\hline 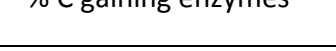 & $10-30$ & $9.84 \pm 2.9$ & $10.86 \pm 7.6$ & $16.4 \pm 6.1$ & $a a b$ & & & $13.8 \pm 3.1$ & $27.0 \pm 7.6$ & $15.9 \pm 6.1$ & $\mathrm{ab} a$ & 9.03 & n.s. \\
\hline$\% \mathrm{CN}$ gaining & $0-10$ & $2.27 \pm 0.9$ & $3.27 \pm 1.0$ & $3.32 \pm 1.9$ & aаa & $342 *$ & $621 *$ & $3.19 \pm 1.1$ & $4.29 \pm 2.1$ & $4.18 \pm 1.5$ & $a a b b$ & $8.49 * * *$ & n.s. \\
\hline enzymes & $10-30$ & $7.12 \pm 2.9$ & $8.31 \pm 2.3$ & $12.7 \pm 7.6$ & aaa & & & $4.81 \pm 3.2$ & $16.1 \pm 7.5$ & $9.15 \pm 5.5$ & $\mathrm{ab} a$ & & \\
\hline$\%$ P gaining enzymes & $0-10$ & $91.3 \pm 2.6$ & $89.3 \pm 2.7$ & $85.3 \pm 5.7$ & $a \mathrm{ab} b$ & $10.4^{* * *}$ & $36.9 * * *$ & $83.8 \pm 6.3$ & $77.9 \pm 5.2$ & $74.3 \pm 11.5$ & $a a b b$ & $14.4 * * *$ & $10.8^{* *}$ \\
\hline & $10-30$ & $83.0 \pm 5.4$ & $80.8 \pm 4.0$ & $70.9 \pm 14.0$ & $a a b$ & & & $81.4 \pm 4.3$ & $56.9 \pm 13.9$ & $74.9 \pm 10.8$ & $a b a b$ & & \\
\hline Sum of oxidative enz. & $0-10$ & $142 \pm 42$ & $111 \pm 35$ & $137 \pm 36$ & aaa & n.s. & $72.4^{* * *}$ & $356 \pm 104$ & $313 \pm 204$ & $464 \pm 217$ & aаa & n.s. & n.s. \\
\hline activity $\left(\mathrm{nmol} \mathrm{g}^{-1} \mathrm{~h}^{-1}\right)$ & $10-30$ & $63 \pm 19$ & $62 \pm 13$ & $68 \pm 34$ & aaa & & & $280 \pm 128$ & $264 \pm 230$ & $376 \pm 235$ & aaa & & \\
\hline
\end{tabular}


Table 3. Concentration of $\mathrm{C}$ and $\mathrm{N}$ and soluble reactive phosphorus (SRP) and their molar ratios in the cold water fraction (CW), concentration of $\mathrm{C}$ and $\mathrm{N}$ in hot water fraction (HW), in hot acid extractable fraction (HAE) fraction and in non-hydrolysable fraction (NON) in peat from the upper $(0-10 \mathrm{~cm})$ and lower (10$30 \mathrm{~cm}$ ) soil layers in pristine, restored and drained BOG and SSF (mean; $n=12 ; \pm S D$ ). Different letters indicate significant differences in particular characteristics among differently managed sites within a given soil layer $(p<0.05)$. The results of factorial ANOVA with management $(\mathrm{M})$ and layer $(\mathrm{L})$ as categorical predictors are shown ( $F$ value); asterisks show the different levels of significance: ${ }^{*} p<0.05,{ }^{* *} p<0.01,{ }^{* * *} p<0.001$.

\begin{tabular}{|c|c|c|c|c|c|c|c|c|c|c|c|c|c|}
\hline & \multirow[b]{2}{*}{ Layer $(\mathrm{cm})$} & \multicolumn{3}{|c|}{ BOG } & \multicolumn{3}{|c|}{ Statistics } & \multicolumn{3}{|c|}{ SSF } & \multicolumn{3}{|c|}{ Statistics } \\
\hline & & Pristine & Restored & Drained & & $\mathrm{M}$ & $\mathrm{L}$ & Pristine & Restored & Drained & & $\mathrm{M}$ & $\mathrm{L}$ \\
\hline \multirow{2}{*}{$\mathrm{CW} \mathrm{C}\left(\mathrm{mg} \mathrm{g}^{-1}\right)$} & $0-10$ & $1.32 \pm 0.4$ & $1.39 \pm 0.6$ & $1.19 \pm 0.7$ & aaa & n.s. & $11.9 * * *$ & $1.00 \pm 0.4$ & $0.88 \pm 0.3$ & $0.93 \pm 0.4$ & aaa & n.s. & n.s. \\
\hline & $10-30$ & $2.20 \pm 1.8$ & $2.20 \pm 0.7$ & $1.86 \pm 0.8$ & aaa & & & $1.10 \pm 0.6$ & $0.94 \pm 0.4$ & $1.07 \pm 0.6$ & аaа & & \\
\hline \multirow{2}{*}{$\mathrm{CW} \mathrm{N}\left(\mathrm{mg} \mathrm{g}^{-1}\right)$} & $0-10$ & $0.06 \pm 0.02$ & $0.07 \pm 0.02$ & $0.07 \pm 0.04$ & aaa & n.s. & $15.3^{* * *}$ & $0.04 \pm 0.04$ & $0.03 \pm 0.02$ & $0.03 \pm 0.01$ & aaa & n.s. & n.s. \\
\hline & $10-30$ & $0.09 \pm 0.05$ & $0.10 \pm 0.03$ & $0.09 \pm 0.02$ & aaa & & & $0.04 \pm 0.04$ & $0.03 \pm 0.01$ & $0.03 \pm 0.02$ & aaa & & \\
\hline \multirow{2}{*}{ CW SRP $\left(\mu g^{-1}\right)$} & $0-10$ & $0.90 \pm 0.4$ & $0.81 \pm 0.5$ & $0.90 \pm 0.3$ & aaa & n.s. & $11.0^{* *}$ & $1.42 \pm 0.8$ & $4.23 \pm 3.4$ & $2.57 \pm 1.6$ & $a b a b$ & $4.18^{*}$ & n.s. \\
\hline & $10-30$ & $1.48 \pm 0.9$ & $1.21 \pm 0.5$ & $1.25 \pm 0.5$ & aaa & & & $1.34 \pm 0.6$ & $1.91 \pm 3.4$ & $3.47 \pm 1.4$ & aaa & & \\
\hline \multirow{2}{*}{ CW C: CW N $\left(\mathrm{mol} \mathrm{mol}^{-1}\right)$} & $0-10$ & $24.3 \pm 4.3$ & $22.7 \pm 3.9$ & $19.8 \pm 5.4$ & aaa & n.s. & n.s. & $39.1 \pm 17.5$ & $39.5 \pm 17.8$ & $41.1 \pm 20.5$ & aaa & n.s. & n.s. \\
\hline & $10-30$ & $25.8 \pm 6.6$ & $24.4 \pm 2.2$ & $22.9 \pm 6.1$ & aaa & & & $38.3 \pm 13.5$ & $41.2 \pm 13.7$ & $43.1 \pm 13.8$ & aaa & & \\
\hline \multirow{2}{*}{ CW C: CW P $\left(\mathrm{mol} \mathrm{mol}^{-1}\right)$} & $0-10$ & $4315 \pm 1976$ & $5134 \pm 1951$ & $3380 \pm 1167$ & aaa & n.s. & n.s. & $2244 \pm 1024$ & $1090 \pm 1096$ & $1411 \pm 994$ & $a b a b$ & $6.12^{* *}$ & n.s. \\
\hline & $10-30$ & $4299 \pm 2379$ & $6236 \pm 5247$ & $4460 \pm 2761$ & aaa & & & $2387 \pm 1131$ & $2348 \pm 2360$ & $1950 \pm 1183$ & aaa & & \\
\hline \multirow{2}{*}{$\mathrm{CW} \mathrm{N}: \mathrm{CW} P\left(\mathrm{~mol} \mathrm{~mol}^{-1}\right)$} & $0-10$ & $178 \pm 79$ & $228 \pm 83$ & $173 \pm 46$ & aaa & n.s. & n.s. & $74.6 \pm 56.4$ & $26.5 \pm 17.7$ & $31.3 \pm 9.9$ & $a b b$ & n.s. & n.s. \\
\hline & $10-30$ & $160 \pm 55$ & $258 \pm 220$ & $191 \pm 91$ & aaa & & & $79.3 \pm 57.1$ & $57.8 \pm 45.2$ & $43.1 \pm 35.3$ & aaa & & \\
\hline \multirow{2}{*}{$\mathrm{HW} \mathrm{C}\left(\mathrm{mg} \mathrm{g}^{-1}\right)$} & $0-10$ & $12.1 \pm 3.9$ & $9.9 \pm 2.5$ & $11.9 \pm 6.9$ & aaa & n.s. & n.s. & $14.5 \pm 5.3$ & $14.0 \pm 7.0$ & $12.3 \pm 8.0$ & aaa & n.s. & $9.08^{* *}$ \\
\hline & $10-30$ & $12.0 \pm 2.4$ & $11.8 \pm 2.8$ & $10.4 \pm 2.3$ & aaa & & & $11.1 \pm 2.4$ & $9.1 \pm 2.9$ & $9.1 \pm 2.1$ & аaа & & \\
\hline \multirow{2}{*}{$\mathrm{HW} N\left(\mathrm{mg} \mathrm{g}^{-1}\right)$} & $0-10$ & $0.4 \pm 0.1$ & $0.3 \pm 0.1$ & $0.3 \pm 0.1$ & aaa & $9.65^{* * *}$ & $8.26 * *$ & $0.5 \pm 0.2$ & $0.4 \pm 0.3$ & $0.4 \pm 0.3$ & aaa & n.s. & $8.47^{* *}$ \\
\hline & $10-30$ & $0.3 \pm 0.1$ & $0.3 \pm 0.1$ & $0.2 \pm 0.1$ & $a a b$ & & & $0.4 \pm 0.1$ & $0.3 \pm 0.1$ & $0.3 \pm 0.1$ & $a b b$ & & \\
\hline \multirow{2}{*}{ HAE C $\left(\mathrm{mg} \mathrm{g}^{-1}\right)$} & $0-10$ & $172 \pm 8$ & $185 \pm 16$ & $161 \pm 18$ & $a b a b$ & $8.34 * *$ & n.s. & $178 \pm 31$ & $140 \pm 34$ & $142 \pm 37$ & $a b a b$ & $12.5^{* * *}$ & n.s. \\
\hline & $10-30$ & $173 \pm 14$ & $174 \pm 6$ & $163 \pm 18$ & aaa & & & $170 \pm 18$ & $127 \pm 33$ & $130 \pm 21$ & $a b b$ & & \\
\hline \multirow{2}{*}{ HAE N $\left(\mathrm{mg} \mathrm{g}^{-1}\right)$} & $0-10$ & $15.3 \pm 1.8$ & $15.9 \pm 3.3$ & $13.3 \pm 1.9$ & $a b a b$ & $3.85^{*}$ & $57.5^{* * *}$ & $10.4 \pm 2.6$ & $13.7 \pm 2.9$ & $14.8 \pm 3.0$ & $a b b$ & $5.4^{* *}$ & n.s. \\
\hline & $10-30$ & $11.4 \pm 4.0$ & $9.1 \pm 2.3$ & $8.9 \pm 2.2$ & aaa & & & $11.7 \pm 3.3$ & $11.2 \pm 1.0$ & $12.5 \pm 1.5$ & aaa & & \\
\hline \multirow{2}{*}{ NON C ( $\left.\mathrm{mg} \mathrm{g}^{-1}\right)$} & $0-10$ & $296 \pm 17$ & $286 \pm 19$ & $312 \pm 26$ & $a b a b$ & $6.48 * *$ & n.s. & $252 \pm 44$ & $283 \pm 57$ & $284 \pm 41$ & aaa & $5.16^{* *}$ & $8.71^{* *}$ \\
\hline & $10-30$ & $290 \pm 20$ & $289 \pm 6$ & $313 \pm 41$ & aaa & & & $273 \pm 40$ & $332 \pm 79$ & $329 \pm 47$ & aаa & & \\
\hline \multirow{2}{*}{ NON N (mg g $\left.{ }^{-1}\right)$} & $0-10$ & $3.0 \pm 0.4$ & $2.6 \pm 0.2$ & $2.8 \pm 0.6$ & aaa & $3.49 *$ & $6.10^{*}$ & $1.7 \pm 0.8$ & $2.4 \pm 0.6$ & $2.3 \pm 0.5$ & aaa & $8.1^{* * *}$ & $11.6^{* *}$ \\
\hline & $10-30$ & $2.6 \pm 0.9$ & $2.0 \pm 0.4$ & $2.6 \pm 1.1$ & aaa & & & $2.2 \pm 0.7$ & $2.8 \pm 0.9$ & $3.2 \pm 0.7$ & $a \mathrm{ab} b$ & & \\
\hline
\end{tabular}



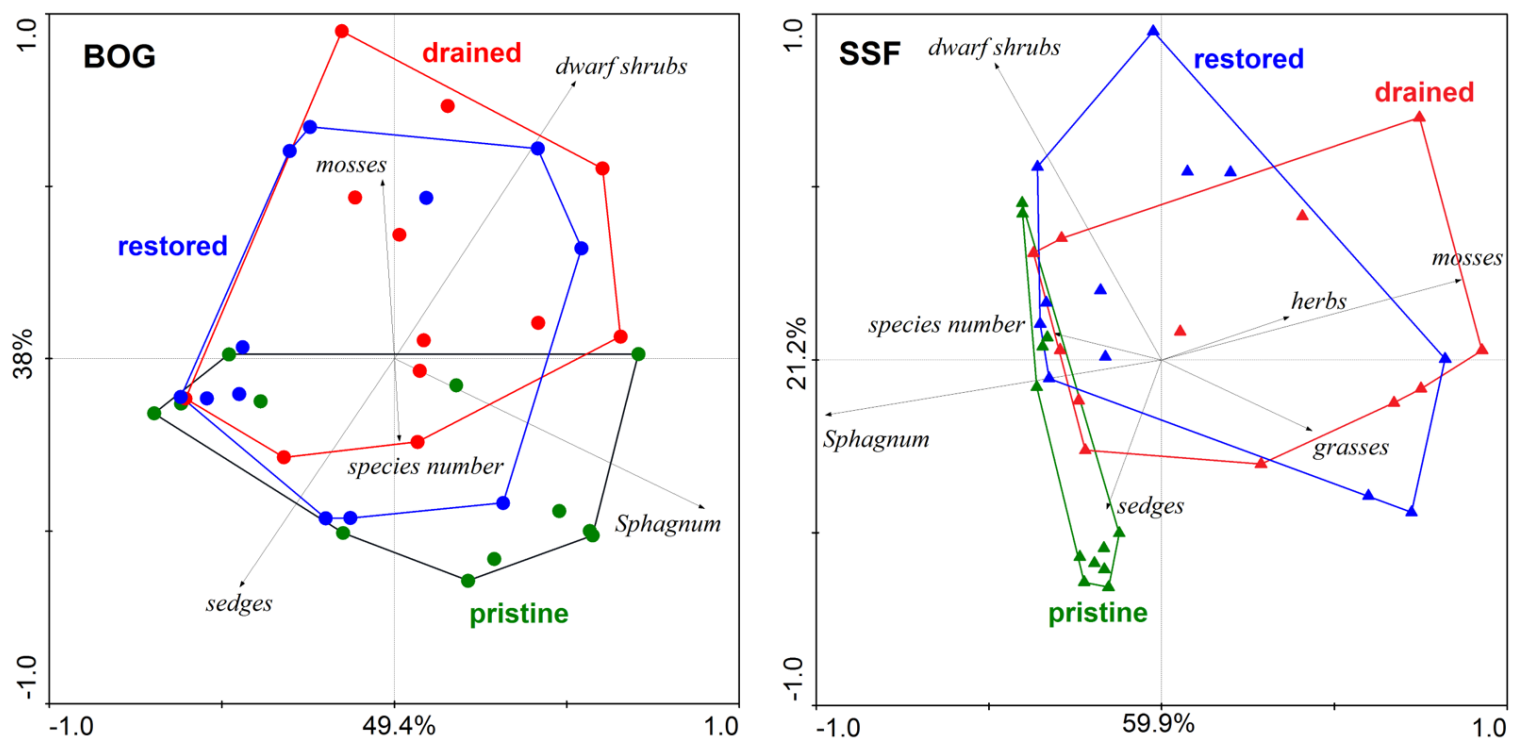

Figure 1. PCA ordination diagram of vegetation community similarity between the pristine (green symbols), drained (red symbols) and restored (blue symbols) BOG and SSF study sites based on the percentage cover of plant functional groups in herbal and moss layers (sedges, dwarf shrubs, grasses, herbs, Sphagnum mosses, other mosses) and number of species. 

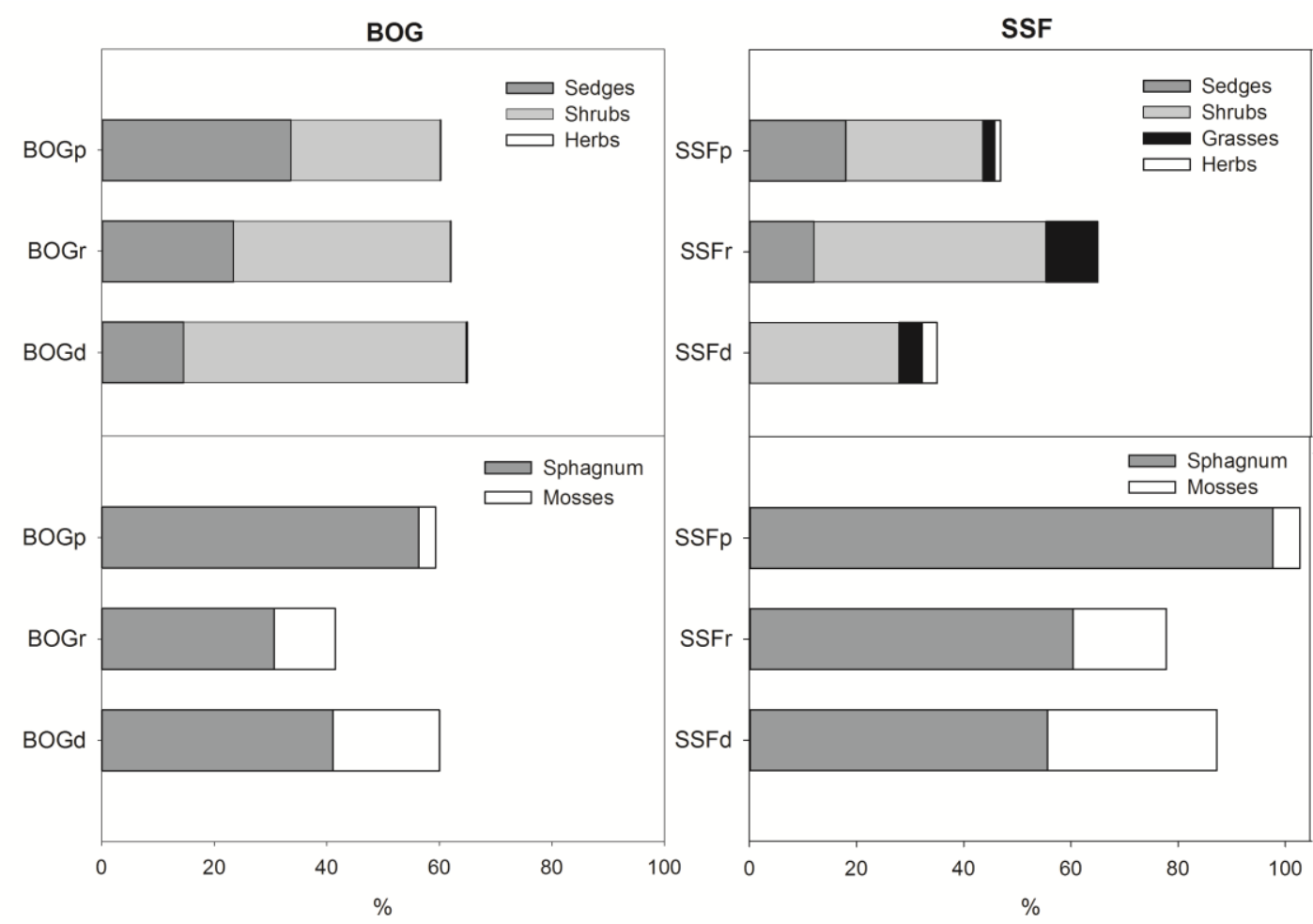

Figure 2. Percentage cover of plant functional groups in herbal and moss layers in pristine, restored and drained BOG and SSF. Mosses represent non-Sphagnum mosses, Shrubs represent ericoid dwarf shrubs. 

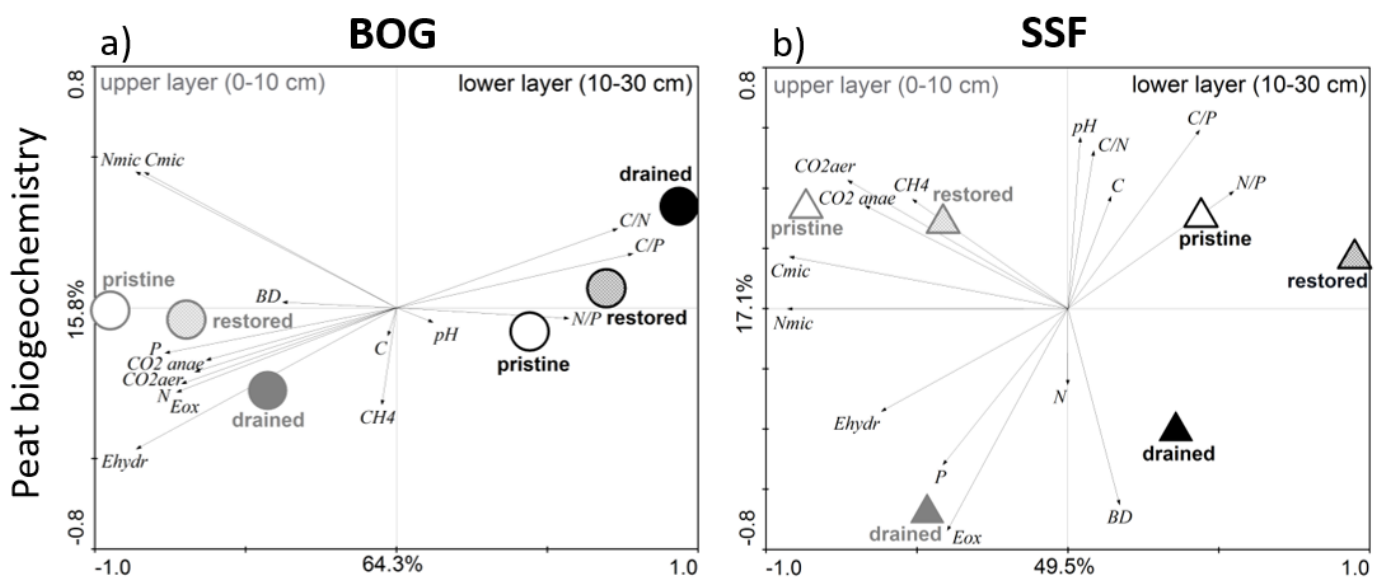

c)

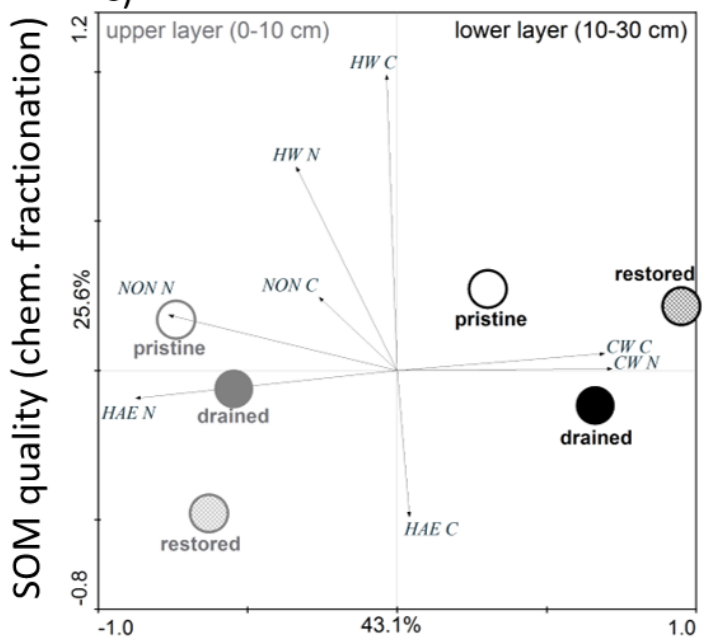

d)

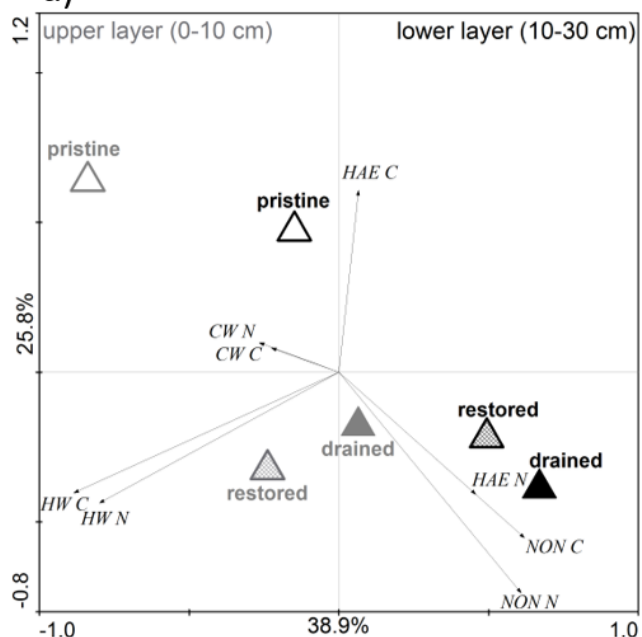

e)
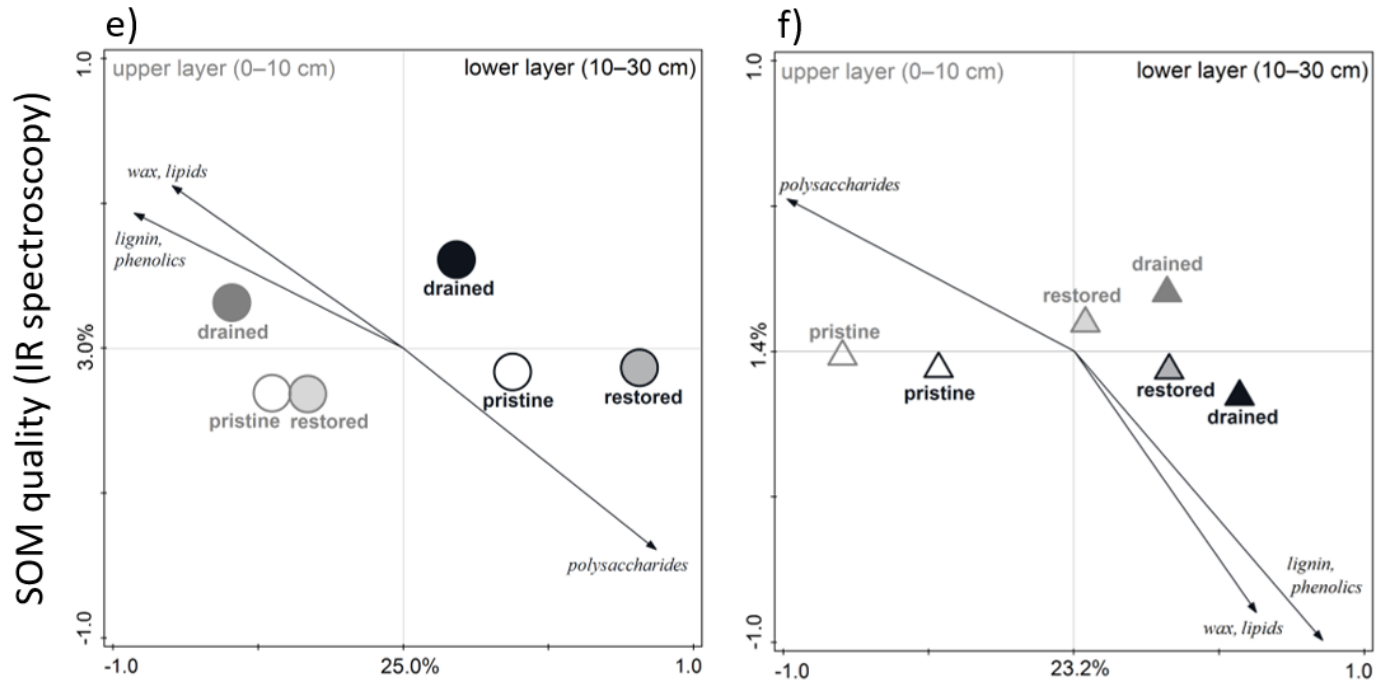

Figure 3. PCA $(a, b, c, d)$ and RDA (e,f) diagrams showing the effect of layer $(0-10 \mathrm{~cm}$ and 10-30 cm) and management (pristine, restored, drained) on peat biogeochemical properties in a) BOG and b) SSF, on the proportional contribution of chemical fractions within soil organic matter in c) BOG and d) SSF, and on the infrared spectroscopy-derived quality of soil organic matter in e) BOG and f) SSF. (BD - bulk density; $\mathrm{CO}$ aer -aerobic $\mathrm{CO}_{2}$ potential production; $\mathrm{CO}$ anaer -anaerobic $\mathrm{CO}_{2}$ potential production; $\mathrm{CH} 4-\mathrm{CH}_{4}$ potential production; Ehydr - total potential activity of hydrolytic enzymes; Eox - total potential activity of oxidative enzymes) 


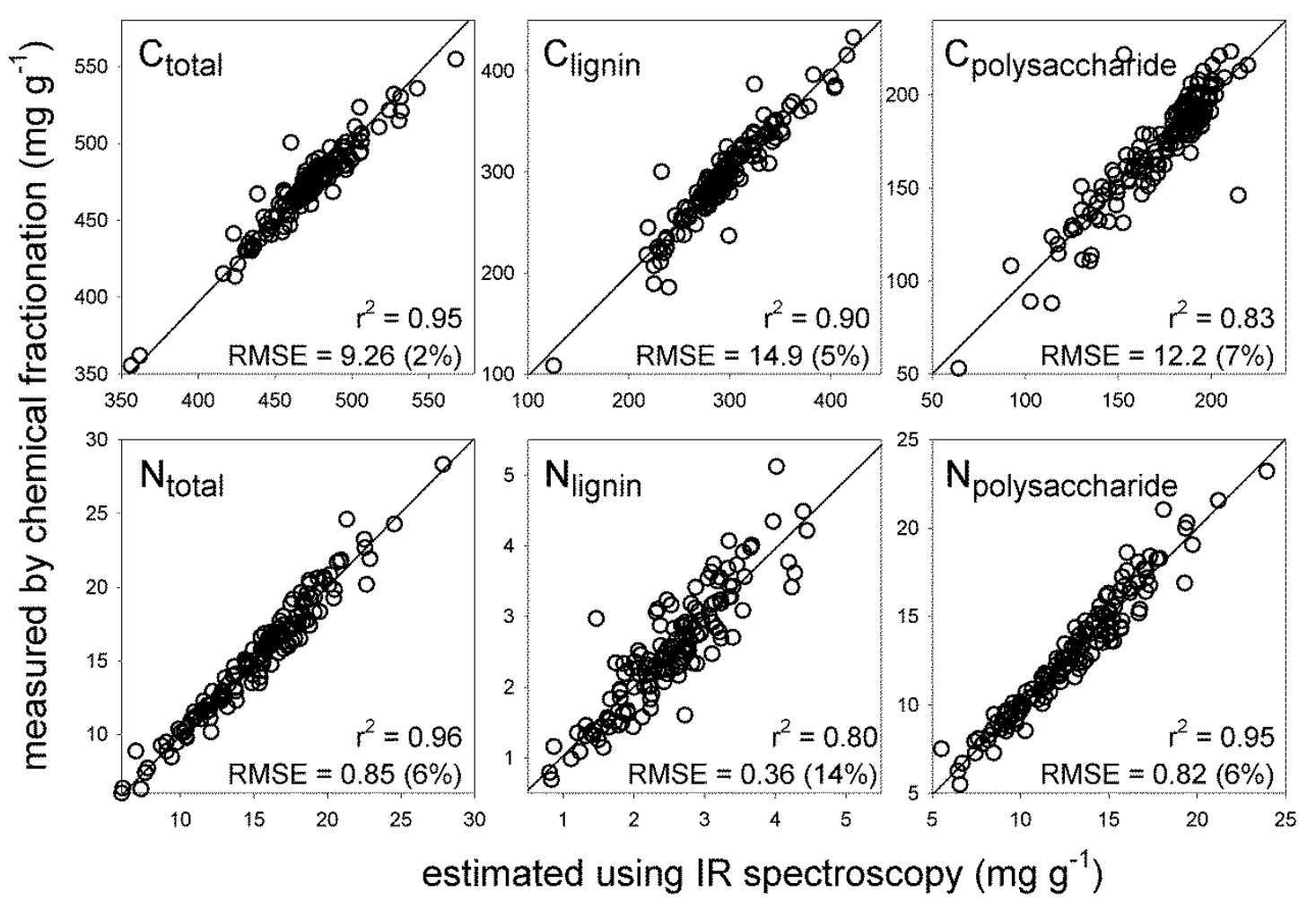

Figure 4. PLS regression models for quantification of SOM quality parameters from infrared spectra. $Y$ axis shows the reference values from chemical fractionation that were used for calibration of the models, and $X$ axis the resulting estimations from infrared spectra. $C_{\text {total }}$ and $\mathrm{N}_{\text {total }}$ represent total $\mathrm{C}$ and $\mathrm{N}$; $\mathrm{C}_{\text {lignin }}$ and $\mathrm{N}_{\text {lignin }}$ represent $\mathrm{C}$ and $\mathrm{N}$ in the non-hydrolysable residue (NON) fraction; $\mathrm{C}_{\text {polysaccharide }}$ and $\mathrm{N}_{\text {polysaccharide }}$ represent $\mathrm{C}$ and $\mathrm{N}$ in the cold water extractable $(\mathrm{CW})+$ hot water extractable $(\mathrm{HW})+$ acid hydrolysable (HAE) fraction. RMSE is the root mean square error of prediction expressed in $\mathrm{mg}$ $\mathrm{g}^{-1}$, with the ratio of RMSE to the average reference value given as a percentage in parentheses. 